\title{
DEVELOPMENT OF A QUANTITATIVE DETECTION CARD FOR HEART-TYPE FATTY ACID-BINDING PROTEIN BASED ON BACKGROUND FLUORESCENCE QUENCHING IMMUNE CHROMATOGRAPHY
}

\author{
KARTE ZA KVANTITATIVNU DETEKCIJU SRČANOG TIPA MASNE KISELINE-VEZUJUĆEG \\ PROTEINA ZASNOVANOG NA FLUORESCENTNOJ IMUNOHROMATOGRAFIJI
}

\author{
Wei Zhang ${ }^{1}$, Junlei Chen ${ }^{2}$, Xinxia $\mathrm{Li}^{1,3}$, Yuwen Wang ${ }^{4}$, Jiutong $\mathrm{Li}^{5}$ \\ ${ }^{1}$ Pharmacy Academy of Xinjiang Medical University, Urumqi 830054 \\ ${ }^{2}$ Chemistry and Chemical Engineering Academy of Xinjiang Normal University, Urumqi 830054 \\ ${ }^{3}$ State Key Laboratory of Cause and Prevention Study of Disease of High Incidence in Central Asia Jointly \\ Constructed by Ministry of Science and Technology and Xinjiang Uygur Autonomous Region, Urumqi 830001 \\ ${ }^{4}$ Xinjiang uygur autonomous region center of disease control and prevention, Urumqi 830002 \\ ${ }^{5}$ Shanghai Simp Bio-Science Co., Ltd., Shanghai 201800
}

\begin{abstract}
Summary
Background: To establish a fast and simple quantitative method for detection of heart-type fatty acid-binding protein (H-FABP) in serum based on a background fluorescence quenching immunochromatographic assay.

Methods: A detection card based on the double-antibody sandwich double-antibody method with background fluorescence quenching was developed for quantitative measurement of $\mathrm{H}-\mathrm{FABP}$ in serum. The optimal concentrations of control for coating the test and control lines were determined as well as the concentrations of gold-labeled antibodies used in preparing the detection system. The detection method for H-FABP in serum was established and validated using real-world clinical samples.

Results: The optimal concentrations of labeling antibody and coating antibody were $5.0 \mu \mathrm{g} / \mathrm{mL}$ and $1.0 \mathrm{mg} / \mathrm{mL}$, respectively. The test card had a sensitivity of $1.15 \mathrm{ng} / \mathrm{mL}$ over a linear concentration range of 0-100 ng/mL. Based on three batches prepared for testing the card, the relative standard deviation (RSD) within batches was less than 15\% without a significant difference $(P=0.942)$. The detection method was tested against common interfering substances in serum, such as bilirubin, triglyceride and serum anticoagulants ethylenediamine tetraacetic acid (EDTA), heparin,
\end{abstract}

\section{Kratak sadržaj}

Uvod: Cilj ovog rada je bio da se izradi brz i jednostavan kvantitativni metod za detekciju srčanog vezujućeg proteina za masne kiseline (H-FABP) u serumu na osnovu fluorescentnog imunohromatografskog određivanja.

Metode: Detekciona karta se zasniva na duploj antibodi sendvič duploj-antibodi metodi zasnovanoj na fluorescenciji i razvijenoj za kvantitativno merenje $\mathrm{H}$-FABP u serumu. Određene su optimalne koncentracije za presvlačenje linija testa i kontrola kao i koncentracije antitela označenih zlatom pri pripremi samog sistema. Uspostavljen je detekcioni metod za H-FABP u serumu i validiran primenom priznatih svetskih kliničkih metoda.

Rezultati: Optimalne koncentracije označenih anititela i presvučenih antitela bile su $5,0 \mu \mathrm{g} / \mathrm{mL}$ odnosno $1,0 \mathrm{mg} / \mathrm{mL}$. Test karta imala je osetljivost $1,15 \mathrm{ng} / \mathrm{mL}$ u opsegu linearne koncentracije od 0-100 ng/mL. Na osnovu pripremljene tri grupe uzoraka za ispitivanje karte dobijena je relativna standardna devijacija (SD) između grupa manja od 15\% bez značajnih razlika ( $P=0,942)$. Metod detekcije ispitivan je naspram uobičajenih interferujućih supstanci u serumu, kao što su bilirubin, trigliceridi i serumski antikoagulansi etilendiamin tetrasirćetna kiselina (EDTA), heparin i natrijum citrat $\mathrm{i}$ pri tom nije nađena bilo kakva interferencija. Metoda je

Address for correspondence:

Xinxia Li

e-mail: Ixx6668@163.com

Yuwen Wang: wangyw1966@163.com

Jiutong Li: 2330617483@qq.com

List of abbreviations: FABPs, Fatty acid-binding proteins; H-FABP Heart-type fatty acid-binding protein; AMI, Acute myocardial infarction; ACS, Acute coronary syndrome; CK-MB, Creatine kinase MB; LTIA, Latex turbidimetric immunoassay. 
and sodium citrate, and no significant cross-reaction was detected. The test method was further validated with 50 clinical serum samples, and the test results were comparable with standard reference detection methods with good correlation $(R=0.95)$.

Conclusion: Our study presents a new method with strong specificity and sensitivity for the detection of H-FABP in serum, which could promote $\mathrm{H}-\mathrm{FABP}$ detection in a broad range of applications.

Keywords: heart-type fatty acid binding protein, background fluorescence quenching, immunochromatography

\section{Introduction}

Fatty acid-binding proteins (FABPs) are small cytoplasmic proteins that are abundantly expressed in tissues with active fatty acid metabolism. Among the nine FABP families that have been identified, hearttype fatty acid-binding protein (H-FABP) has been the most widely studied. Abundantly expressed in cardiomyocytes, H-FABP is a low molecular weight, 14.5-kDa protein composed of 132 amino acids and constituting $5-15 \%$ of cytoplasmic protein in the human heart (1). With a reference concentration of $2.0 \mathrm{ng} / \mathrm{mL}, \mathrm{H}$-FABP levels usually remain low in plasma, but H-FABP is released rapidly upon the onset of acute myocardial infarction (AMI) (2). This increase in $\mathrm{H}-\mathrm{FABP}$ can be detected as early as $30 \mathrm{~min}$ following the onset of $\mathrm{AMI}$, and the $\mathrm{H}$-FABP concentration typically peaks within 6-8 hours after symptom onset. $\mathrm{H}-\mathrm{FABP}$ as a biomarker offers high sensitivity across the full spectrum of acute coronary syndrome (ACS) (3-5). The combination of high sensitivity and early specificity of $\mathrm{H}-\mathrm{FABP}$ makes it a promising biomarker for early diagnosis and treatment of $\mathrm{AMI}$ and ACS that could be superior to the commonly applied Troponin I and Troponin T (initial elevation in blood occurs within 3-6 hours and time-to-peak is 10-48 hours) and creatine kinase MB (CK-MB; initial elevation 3-8 hours and time-to-peak 9-24 hours) (6-9).

Despite establishment of its clinical value a decade ago, available methods for measuring $\mathrm{H}$ FABP concentrations are limited and include radioimmunoassay (RIA) (10), latex turbidimetric immunoassay (LTIA) (11), enzyme-linked immunosorbent assay (ELISA) (12), and colloidal gold immunochromatography (13). Critical drawbacks of these methods have been identified. Specifically, the radioimmunoassay method is limited by its expense and the hazards of preparing and handling radioactive antigen. ELISAs are prone to the introduction of accidental errors during complicated procedures, and the wide application of LTIA is limited by the high cost of testing equipment. A one-step immunochromatography technique (13) for the detection of H-FABP in whole blood samples has been reported with a sensitivity of 6.2 $\mathrm{ng} / \mathrm{mL}$, which barely reaches the cut-off value for the diagnosis of AMI. In the present study, we developed and validated a background fluorescence quenching- zatim validovana na 50 kliničkih serumskih uzoraka, pri čemu su rezultati bili uporedivi sa standardnim detekcionim metodama i dobrom korelacijom $(R=0,95)$.

Zaključak: Naša izučavanja predstavljaju novu metodu sa snažnom specifičnošću i osetljivosti za detekciju H-FABP u serumu, pa se može preporučiti za širu upotrebu.

Ključne reči: srčani tip masne kiseline-vezujući protein, fluorescencija, imunohemotografija

immunochromatographic technique for quantitative detection of H-FABP based on colloidal gold immunochromatography (14). Fluorescence quenching includes static quenching, dynamic quenching, resonance energy transfer and internal filtration effect (IFE). The fluorescent film is fixed on the rubber sheet and will not contact with the solution. The IFE requires that the absorption spectra of the quencher is effectively overlapped with the excitation or emission spectra of the fluorescence film, and that colloidal gold is used as quencher. A uniform fluorescence film was added to the solid phase film of colloidal gold immunochromatography as background fluorescence. The fluorescence intensity ratio was analyzed by detecting the background fluorescence and the test line. The fluorescence intensity ratio was quantitatively determined by detecting the background fluorescence and the test line of the strip. Strong anti-background interference characteristics can eliminate system errors.

\section{Materials and Methods}

\section{Materials}

H-FABP Standard (RDR-9, $100 \mu \mathrm{g}$ ) was purchased from Medix Biochemica. Anti-human H-FABP antibody (FABP3 2302 SPTN $-5,5.1 \mathrm{mg} / \mathrm{mL}$ ) and anti-human H-FABP antibody (FABP3 2304 SPTN-5, $5.0 \mathrm{mg} / \mathrm{mL}$ ) were obtained from Medix Biochemica. Goat anti-mouse polyclonal antibody $(1.0 \mathrm{mg} / \mathrm{mL})$ was purchased from Shanghai Ronghui Biotechnology Co. Bovine serum albumin (lot No. 4529010350) was purchased from Genview. The following reagents were all obtained from Sinopharm Group Chemical Reagent Company: gold chloride (lot No. 20161118), sodium carbonate (lot No. 20140902), sodium bicarbonate (lot No. 20140904), disodium hydrogen phosphate (lot No. 20140902), sodium dihydrogen phosphate (lot No. 20140710), Tween20 (lot No. 20170916), sodium chloride (lot No. 20140818), sucrose (lot No. 20140922), D-trehalose (dehydrated, lot No. Y18J7J18031), sodium citrate (lot No. 20161209), ethylene diamine tetraacetic acid (lot No. 20140829), and heparin sodium (lot No. 20170426). Bilirubin (lot No. 20170623) was purchased from Shanghai Rongsheng Bio-phar- 
maceutical Co., and whole blood control samples (lot No. 11130581) were purchased from Sichuan Xincheng Biotechnology LLC. Serum matrix (lot No. 0010316) was purchased from Biological Industries. Clinical serum samples were kindly provided by Shanghai Xuhui District Central Hospital.

\section{Solution preparation}

The Base1 solution was prepared by dissolving $8.48 \mathrm{~g}$ Tris Base, $200 \mathrm{~g}$ sucrose, $50 \mathrm{~g}$ trehalose, and $10 \mathrm{~g}$ bovine serum albumin in $1000 \mathrm{~mL}$ pure water. The Base2 solution was prepared by dissolving 2.42 $\mathrm{g}$ Tris Base, $1 \mathrm{~g}$ PEG20000, $2 \mathrm{~g}$ sucrose, $20 \mathrm{~g}$ bovine serum albumin, and $3 \mathrm{~mL}$ Tween-20 in $1000 \mathrm{~mL}$ pure water. The $\mathrm{pH}$ was adjusted to 8.0 with $6 \mathrm{~mol} / \mathrm{L}$ hydrochloric acid. Base1 solution and Base2 solution were mixed in a ratio of 3: 7 .

Serial dilutions of H-FABP solution were prepared from $100 \mu \mathrm{g} / \mathrm{mL} \mathrm{H}$-FABP standard solution to obtain 1.0, 2.0, 5.0, 10.0, 20.0, 50.0, and 100.0 $\mathrm{ng} / \mathrm{mL}$ standard solutions.

\section{Gold colloid-conjugated antibodies}

Antibodies were conjugated with gold colloid via the following method. Briefly, auric chloride $\left(\mathrm{AuCl}_{3}\right)$ was weighed and dissolved in deionized water to form $0.01 \%$ auric chloride solution. Then $100 \mathrm{~mL}$ solution was heated to boiling, and $2 \mathrm{~mL}$ trisodium citrate solution $(1 \%)$ was added. The mixture was stirred vigorously until the solution turning claret, followed by heating for another $10 \mathrm{~min}$. Then the solution was cooled down to room temperature. The colloidal gold solution was adjusted to $\mathrm{pH} 8.0$ with potassium carbonate solution $(0.1 \%)$. First, $1 \mathrm{~mL}$ of gold colloid solution was added to each test tube, and then $3 \mu \mathrm{L}$, $5 \mu \mathrm{L}$, and $7 \mu \mathrm{L} \mathrm{H}-\mathrm{FABP}$ antibody solution was added to respective tubes, followed by addition of $20 \mu \mathrm{L}$ phosphate-buffered saline (PBS) solution containing $10 \%$ bovine serum albumin. The mixture was centrifuged at $9000 \mathrm{rpm}$ and $4{ }^{\circ} \mathrm{C}$ for $15 \mathrm{~min}$. The supernatant was aspirated and discarded, and the pellet was suspended in matrix solution added for a total of $200 \mu \mathrm{L}$. Finally, $10 \mu \mathrm{L}$ of the solution was taken and dried in a vacuum for $3 \mathrm{~h}$. The optical density of colloid-conjugated antibody was measured at $520 \mathrm{~nm}$ using an ultraviolet spectrophotometer (L6S, Shanghai Instrument Electric Analysis Instrument Company).

Immobilization of antibody onto nitrocellulose membrane

Anti-human H-FABP monoclonal antibody was immobilized along a straight line at a distance of 1.0 $\mathrm{cm}$ from the edge of a nitrocellulose membrane (NC). This line served as a detection line for binding of $\mathrm{H}$ $\mathrm{FABP} /$ gold colloid-conjugated antibody complexes (Figure 1). The membrane was dried overnight at room temperature.

\section{Assembly of test system}

The test system is composed of two parts: the test cup and test panel. A schematic diagram of the plasma panel test is shown in Figure 1. The test cup is where binding occurs between the plasma sample and gold colloid-conjugated antibody complex. The

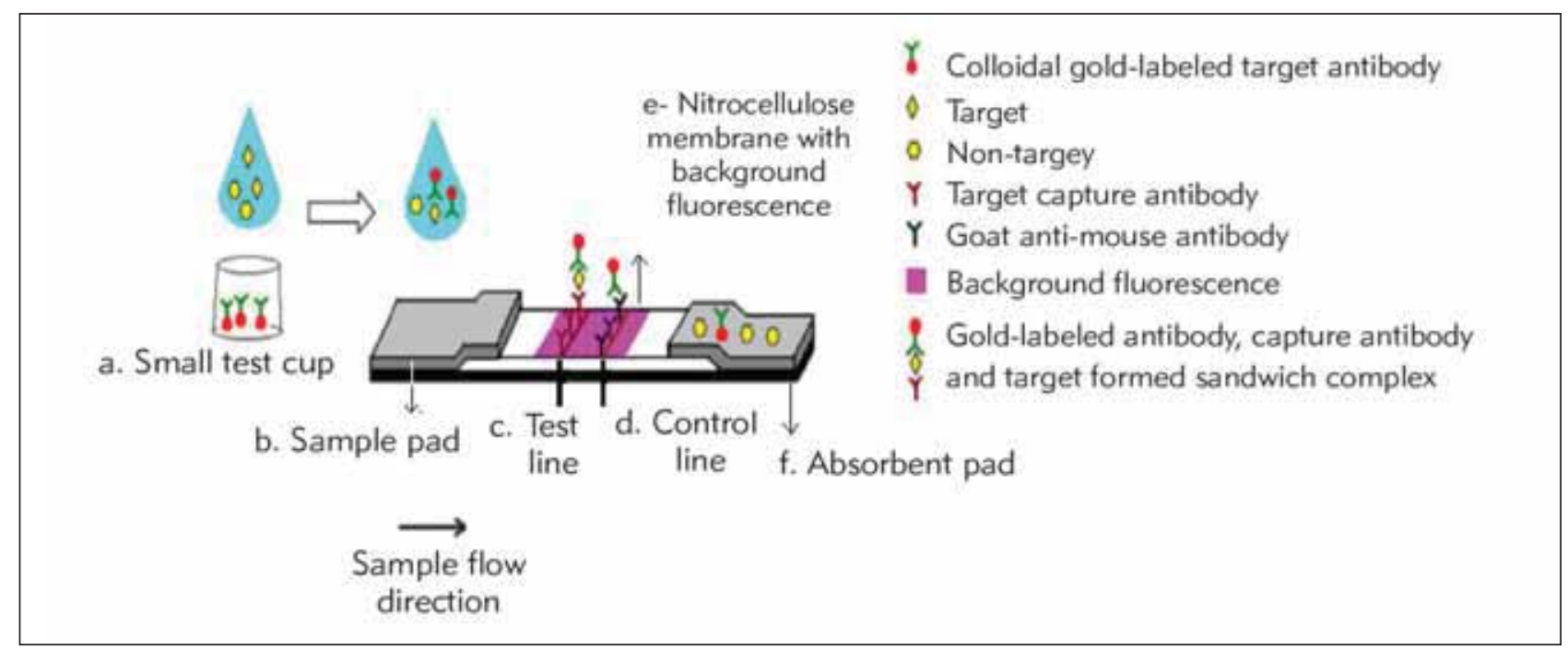

Figure 1 Schematic diagram of plasma panel test for H-FABP.

a. Small cup with bottom coated with gold colloid-conjugated antibodies; b. sample pad to which the sample plasma is added; $c$. test line (T-line), coated with capture antibody; $d$. control line (C-line); e. nitrocellulose membrane, on which background fluorescence for T-line and $\mathrm{C}$-line is read; and $\mathrm{f}$. absorbent pad that absorbs excess sample solution. 


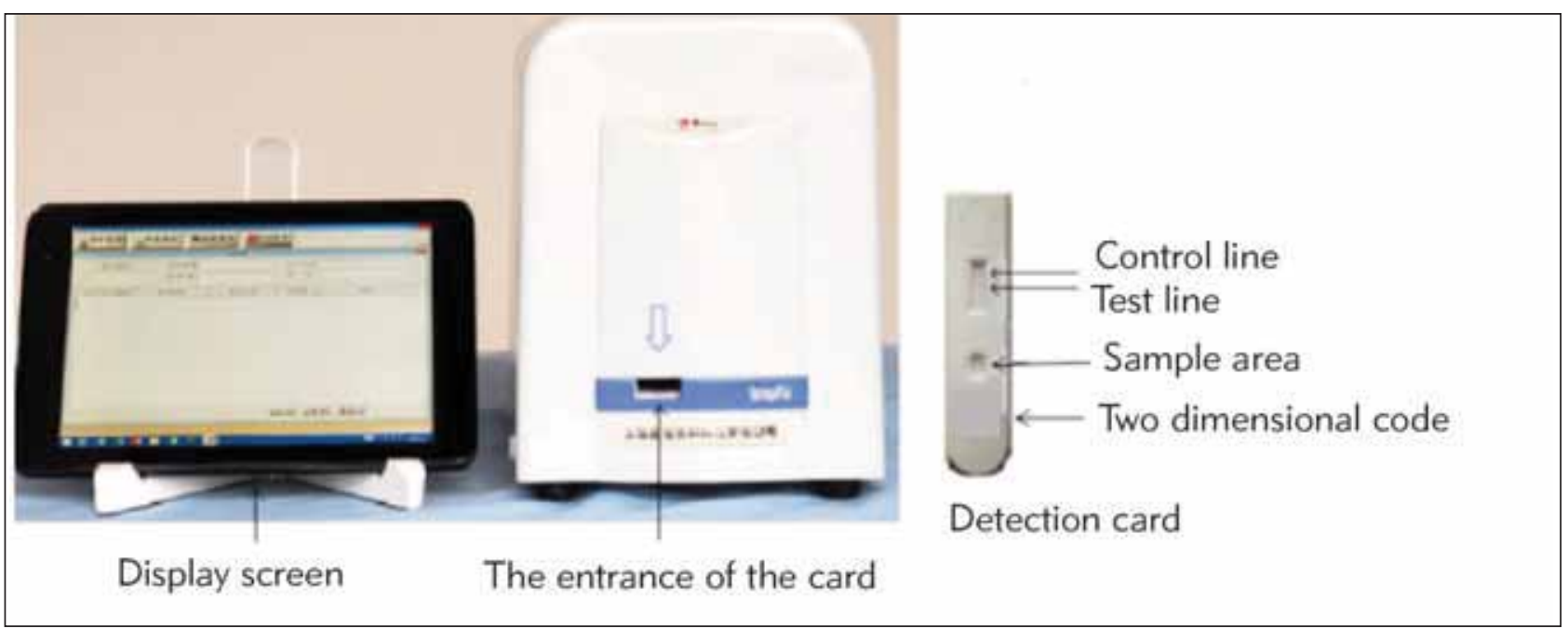

Figure 2 Background fluorescence quenching immunochromatographic analyzer and test card.

combined sample is then added to the test strip in the test card, which has a sample pad, nitrocellulose membrane bearing the test line (T-line) and control line (C-line), and an absorbent pad. The sample pad is used for dropping the sample solution. T-line is coated with capture antibody and C-line is coated with sheep anti-mouse antibody and used to detect the effectiveness of the test strip. Nitrocellulose membrane is used to carry $\mathrm{T} / \mathrm{C}$ line. The absorbent pad is used to absorb excess sample solution (Figure 1). The sample pad containing gold colloid-conjugated antibody was cut into $21 \mathrm{~mm}$-long and $3.4 \mathrm{~mm}$-wide strips. The absorbent pad was cut into $19 \mathrm{~mm}$-long and $3.4 \mathrm{~mm}$-wide strips. The H-FABP antibodies were immobilized on the nitrocellulose membrane, which was then cut into 65-mm-long and 3.4-mm-wide strips. A sample pad strip was attached to one side of a nitrocellulose membrane strip. A absorbent pad strip was attached to other side of a nitrocellulose membrane strip. Next, a cellulose membrane for absorbing excess plasma and $\mathrm{H}-\mathrm{FABP} /$ gold colloidconjugated antibody complexes was attached to the other side of the nitrocellulose membrane strip. A background fluorescence quenching immunochromatographic analyzer (Shanghai Simp Bio-Science Co., Ltd.), as shown in Figure 2, was used for immunochromatographic detection. The analyzer was used for detection of respective analytes conjugated with gold colloid and antibodies on the test card.

\section{Assay procedure for the test panel}

An $80-\mu \mathrm{L}$ aliquot of plasma sample is applied to the sample cup coated with colloidal gold/antibody complex. After binding of H-FABP in the sample with gold colloid-conjugated antibody complex, a $60-\mu \mathrm{L}$ aliquot is dropped into the sample well of the test card. The sample moves along the pad through capillary migration and combines to the NC generating background fluorescence. The H-FABP/colloidal gold-labeled antibody complex binds with capture antibody immobilized along the T-line to form a double antibody sandwich complex, causing background fluorescence quenching and development of a visible T-line. The C-line serves as the quality control line. The goat anti-mouse antibody combines with the immobilized antibody and develops the C-line. The intensity of background fluorescence is set as $\mathrm{F}_{0}$, and the fluorescence intensity of the $\mathrm{T}$-line as $\mathrm{F}_{1}$. Then the fluorescence quenching degree $\left(F_{0} / F_{1}\right)$ is related to the H-FABP concentration in the plasma sample.

\section{Statistical analysis}

Statistical Package for the Social Sciences (SPSS, version 17.0, Chicago, IL) was used for all analyses. Data are presented as means \pm standard deviation (SD). Statistical significance was set at $\mathrm{P}<0.05$.

\section{Results}

Detection of capture antibody at the T-line

Test cards on which H-FABP antibodies were immobilized from solutions at varying concentrations $(0.5,0.75,1.0$, or $1.5 \mathrm{mg} / \mathrm{mL})$ were prepared to determine the optimal capture concentration. For each respective capture antibody concentration, tests were conducted with varying $\mathrm{H}-\mathrm{FABP} /$ gold colloidconjugated antibody complex solutions $(0,1,5,10$, 25,50 , and $100 \mathrm{ng} / \mathrm{mL}$ ). For measurement, $60 \mu \mathrm{L}$ of complex solution was added to the test card and the $\mathrm{F}_{0} / \mathrm{F}_{1}$ values were measured after $15 \mathrm{~min}$ of chromatography at room temperature. As shown in Figure 3, when the sample cup was coated using $5 \mu \mathrm{L}$ gold colloid-conjugated antibody complex and $1 \mathrm{mg} / \mathrm{mL}$ capture antibody solution was used for immobilization 


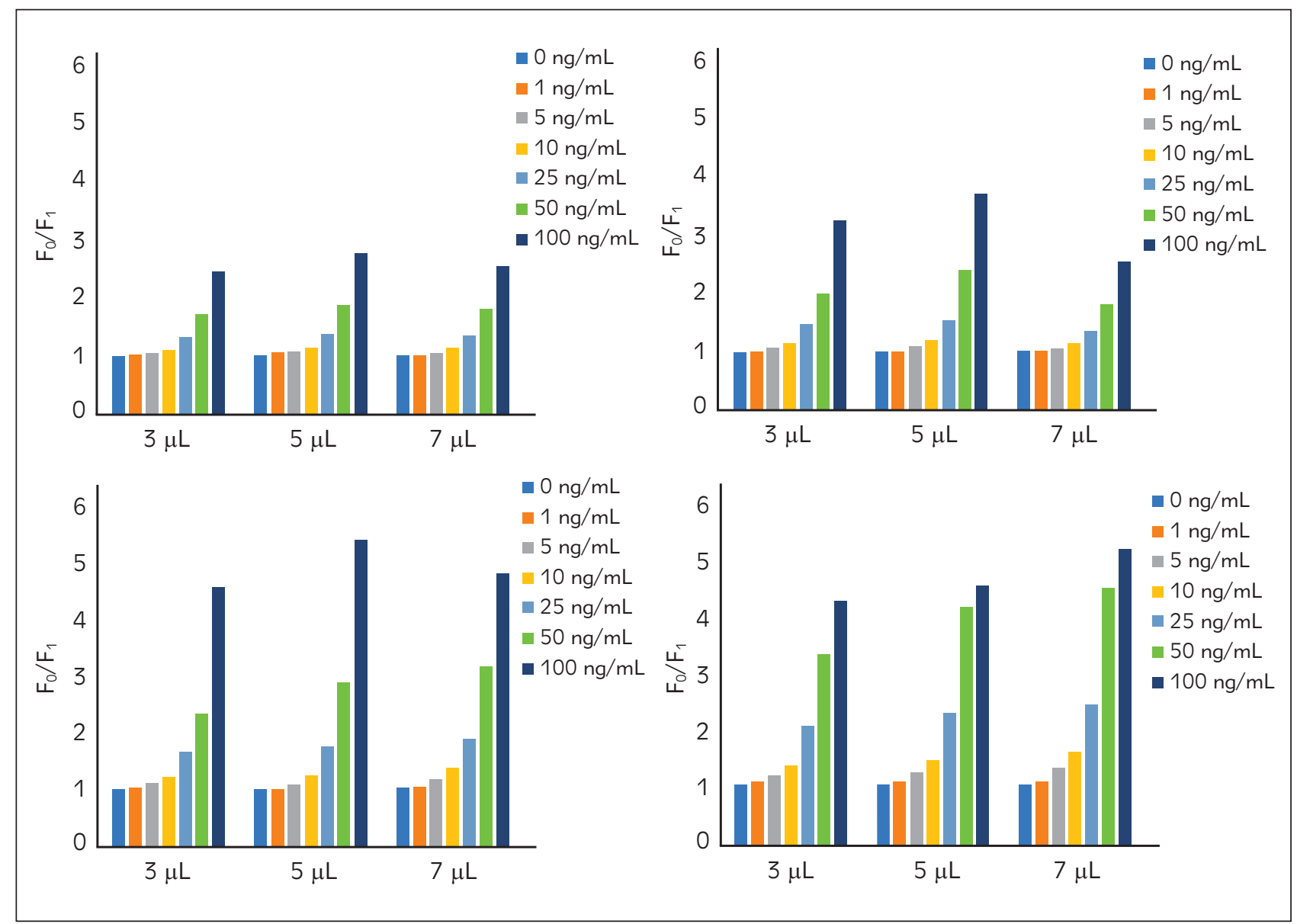

Figure 3 Background fluorescence quenching with varying amounts of immobilized capture antibody on the T-line and a series of $\mathrm{H}-\mathrm{FABP} /$ gold colloid-conjugated antibody complex concentrations.

$\mathrm{H}$-FABP antibodies were immobilized on test cards from solutions of varying concentrations $(0.5,0.75,1.0$, or $1.5 \mathrm{mg} / \mathrm{mL})$ for testing to determine the optimal capture concentration. Briefly, serial H-FABP/gold colloid-conjugated antibody complex solutions were prepared by mixing 3, 5, or $7 \mathrm{~mL}$ of $1.0 \mathrm{mg} / \mathrm{mL} \mathrm{H}$-FABP solution with gold colloid-conjugated antibody solution prepared as described in the "Materials and Methods«. The H-FABP capture solution was diluted in PBS to $0.5,0.75,1.0$, or $1.5 \mathrm{mg} / \mathrm{mL}$. The T-line on the nitrocellulose membrane was marked at density of $0.9 \mathrm{~mL} / \mathrm{cm}$. Goat anti-mouse H-FABP antibody $(0.2 \mathrm{mg} / \mathrm{mL})$ was immobilized on the C-line at a density of $0.9 \mathrm{~mL} / \mathrm{cm}$. After application of the T-line and C-line, the nitrocellulose membrane was dried at room temperature for 8 hours. Finally, $80-\mathrm{mL}$ solutions of different $\mathrm{H}-\mathrm{FABP} /$ gold colloid-conjugated antibody complex solutions were applied to test cards on which the T-line was prepared by immobilizing varying amounts of capture antibody: $0.5 \mathrm{mg} / \mathrm{mL}(\mathrm{a}), 0.75 \mathrm{mg} / \mathrm{mL}(\mathrm{b}), 1.0 \mathrm{mg} / \mathrm{mL}(\mathrm{c})$, and $1.5 \mathrm{mg} / \mathrm{mL}(\mathrm{d})$.

on the test card at the T-line, the most significant increasing trend of the $F_{0} / F_{1}$ ratio was observed.

\section{Validation of test method}

The test card was validated with serially diluted solutions of H-FABP (1.0, 2.0, 5.0, 10.0, 20.0, 50.0, and $100.0 \mathrm{ng} / \mathrm{mL}$ ). With the concentration of test solution along the $x$-axis and $F_{0} / F_{1}$ along the $y$-axis, the regression equation was fitted to be: $Y=0.0001+$ $0.0 .0311+1.0007$, with a correlation coefficient $=$ 0.9997 , which indicated that the test method provides good linear correlation over an H-FABP concentration range of $0-100.0 \mathrm{ng} / \mathrm{mL}$ (Table I). Blank solution was taken as the negative control for measurement of the minimum detection limit, which was found to be $1.15 \mathrm{ng} / \mathrm{mL}$. Measurement of 5.0, 25.0, and $50.0 \mathrm{ng} / \mathrm{mL} \mathrm{H-FABP}$ standard solutions showed that the RSDs for each concentration were $10.8 \%, 6.8 \%$, and $9.2 \%$, respectively, indicating the high repeatability of this assay (Table II).

Variation between batches was measured further using three batches of test cups coated with gold colloid-conjugated antibody complex and test cards with immobilized H-FABP capture antibody. The three batches were validated using $\mathrm{H}$-FABP standard solutions $(5.0,25.0$, and $50.0 \mathrm{ng} / \mathrm{mL}$ ), and the calculated RSDs for each concentration are listed in Table III. The results for the three groups were employed for variance analysis, which yielded a $\mathrm{P}=0.942$. 
Table I Validation with H-FABP standard solutions: H-FABP concentration in solution vs. $F_{0} / F_{1}$.

\begin{tabular}{|l|c|c|c|c|c|c|c|}
\hline $\begin{array}{l}\mathrm{H}-\mathrm{FABP} \text { concentration } \\
(\mathrm{ng} / \mathrm{mL})\end{array}$ & 0 & 1 & 5 & 10 & 25 & 50 & 100 \\
\hline $\mathrm{F}_{0} / \mathrm{F}_{1}$ & $1.036 \pm 0.01$ & $1.050 \pm 0.02$ & $1.142 \pm 0.01$ & $1.303 \pm 0.06$ & $1.808 \pm 0.04$ & $2.951 \pm 0.25$ & $5.467 \pm 0.95$ \\
\hline
\end{tabular}

$\mathrm{n}=3$. Correlation coefficient $=0.9997$

Table II Repeatability of the test results.

\begin{tabular}{|l|c|c|c|}
\hline H-FABP concentration $(\mathrm{ng} / \mathrm{mL})$ & $\mathrm{F}_{0} / \mathrm{F}_{1}$ & Actual concentration $(\mathrm{ng} / \mathrm{mL})$ & RSD (\%) \\
\hline $5.0 \pm 0.5$ & $1.1659 \pm 0.02$ & $6.03 \pm 0.65$ & 10.8 \\
\hline $25.0 \pm 2.5$ & $1.6861 \pm 0.06$ & $21.41 \pm 1.46$ & 6.8 \\
\hline $50.0 \pm 5.0$ & $2.6232 \pm 0.13$ & $43.17 \pm 2.87$ & 9.2 \\
\hline
\end{tabular}

$n=10$. No significant difference was detected according to the RSDs for the different concentrations.

Table III Test results for different sample batches.

\begin{tabular}{|c|c|c|c|c|}
\hline $\begin{array}{c}\text { Batch } \\
\text { No. }\end{array}$ & H-FABP concentration $(\mathrm{ng} / \mathrm{mL})$ & $\mathrm{F}_{0} / \mathrm{F}_{1}$ & Actual concentration $(\mathrm{ng} / \mathrm{mL})$ & $\mathrm{RSD}(\%)$ \\
\hline \multirow{2}{*}{1} & $5.0 \pm 0.5$ & $1.3074 \pm 0.02$ & $4.77 \pm 0.39$ & 8.3 \\
\cline { 2 - 5 } & $25.0 \pm 2.5$ & $2.6489 \pm 0.05$ & $22.17 \pm 0.58$ & 4.6 \\
\cline { 2 - 5 } & $50.0 \pm 5.0$ & $4.8288 \pm 0.18$ & $45.99 \pm 2.02$ & 5.7 \\
\cline { 2 - 6 } & $5.0 \pm 0.5$ & $1.3520 \pm 0.02$ & $5.56 \pm 0.32$ & 5.3 \\
\cline { 2 - 6 } & $25.0 \pm 2.5$ & $2.6163 \pm 0.10$ & $21.80 \pm 1.14$ & 7.2 \\
\hline \multirow{2}{*}{3} & $50.0 \pm 5.0$ & $4.5676 \pm 0.28$ & $43.11 \pm 3.09$ & 13.0 \\
\cline { 2 - 6 } & $5.0 \pm 0.5$ & $1.3249 \pm 0.04$ & $5.07 \pm 0.66$ & 1.2 \\
\hline
\end{tabular}

$n=10$. No significant difference was detected according to the RSDs for different concentrations.

Table IV Recovery rates in test samples.

\begin{tabular}{|l|c|c|c|c|}
\hline$F_{0} / F_{1}$ & Added amount $(\mathrm{m} / \mathrm{ng})$ & Measured amount $(\mathrm{m} / \mathrm{ng})$ & Recovery rate $(\%)$ & RSD (\%) \\
\hline $1.2309 \pm 0.03$ & 8.06 & $8.49 \pm 0.96$ & 96.2 & 11.5 \\
\hline $1.3969 \pm 0.02$ & 14.35 & $13.80 \pm 0.64$ & 104.1 & 5.8 \\
\hline $2.009 \pm 0.06$ & 28.76 & $29.94 \pm 1.53$ & 5.2 \\
\hline
\end{tabular}

$n=3$. No significant difference was detected according to the RSDs for the tested concentrations. 
Table V Potential interference of co-present substances in H-FABP solutions.

\begin{tabular}{|c|c|c|c|c|}
\hline Interfering substance & $\begin{array}{l}\text { H-FABP concentration } \\
(\mathrm{ng} / \mathrm{mL})\end{array}$ & $\mathrm{F}_{0} / \mathrm{F}_{1}$ & $\begin{array}{c}\text { Actual H-FABP } \\
\text { concentration }(\mathrm{ng} / \mathrm{mL})\end{array}$ & $\begin{array}{c}\text { Recovery rate } \\
(\%)\end{array}$ \\
\hline \multirow{3}{*}{ Bilirubin } & $5.0 \pm 0.5$ & 1.2222 & 5.01 & 95.3 \\
\hline & $25.0 \pm 2.5$ & 1.9630 & 24.34 & 97.3 \\
\hline & $50.0 \pm 5.0$ & 3.0209 & 49.48 & 101.3 \\
\hline \multirow{3}{*}{ Hemoglobin } & $5.0 \pm 0.5$ & 1.1620 & 3.22 & 61.3 \\
\hline & $25.0 \pm 2.5$ & 1.7103 & 18.04 & 72.1 \\
\hline & $50.0 \pm 5.0$ & 2.5881 & 39.36 & 80.6 \\
\hline \multirow{3}{*}{ Triglyceride } & $5.0 \pm 0.5$ & 1.2235 & 5.05 & 96.1 \\
\hline & $25.0 \pm 2.5$ & 2.1023 & 27.73 & 110.8 \\
\hline & $50.0 \pm 5.0$ & 3.3403 & 56.85 & 116.4 \\
\hline \multirow{3}{*}{ Heparin sodium } & $5.0 \pm 0.5$ & 1.2689 & 6.33 & 109.5 \\
\hline & $25.0 \pm 2.5$ & 1.9630 & 31.86 & 117.3 \\
\hline & $50.0 \pm 5.0$ & 4.0844 & 83.85 & 111.2 \\
\hline \multirow[t]{3}{*}{ EDTA } & $5.0 \pm 0.5$ & 1.2594 & 6.07 & 115.6 \\
\hline & $25.0 \pm 2.5$ & 2.0646 & 26.82 & 107.2 \\
\hline & $50.0 \pm 5.0$ & 3.0637 & 50.47 & 103.3 \\
\hline \multirow[t]{3}{*}{ Sodium citrate } & $5.0 \pm 0.5$ & 1.1998 & 4.35 & 82.8 \\
\hline & $25.0 \pm 2.5$ & 1.9165 & 23.18 & 92.6 \\
\hline & $50.0 \pm 5.0$ & 3.0923 & 51.13 & 104.7 \\
\hline
\end{tabular}

$n=3$. Recovery rates for substances other than hemoglobin ranged from $80 \%-120 \%$, indicating no significant effect on $\mathrm{H}-\mathrm{FABP}$ measurement.

The recovery rate was also validated for the test system. Briefly, $20-\mu \mathrm{L}, 30-\mu \mathrm{L}$, and $50-\mu \mathrm{L}$ aliquots of $\mathrm{H}$ FABP solution $(100 \mathrm{ng} / \mathrm{mL})$ were added to $5.0 \mathrm{ng} / \mathrm{mL}$, $10.0 \mathrm{ng} / \mathrm{mL}$, and $25.0 \mathrm{ng} / \mathrm{mL}$ standard solutions to prepare test solutions of high, medium, and low concentrations, respectively. The $F_{0} / F_{1}$ ratio was measured for each concentration, and the results fell within the range of $85 \%-115 \%$, indicating that the detection method was accurate and reliable (Table IV).

\section{Interference by other substances present in serum}

Possible interference by various substances was investigated using plasma control samples containing $\mathrm{H}$-FABP at concentrations of $5.0,25.0$, and 50.0 $\mathrm{ng} / \mathrm{mL}$ as well as bilirubin $(2 \mathrm{mg} / \mathrm{mL}$ ), hemoglobin $(10 \mathrm{mg} / \mathrm{mL})$, triglyceride $(40 \mathrm{mg} / \mathrm{mL})$, heparin sodium $(100 \mathrm{mg} / \mathrm{mL})$, EDTA $(1.5 \mathrm{mg} / \mathrm{mL})$, or sodium citrate $(0.1 \mathrm{mg} / \mathrm{mL})$. All recovery rates for test solutions fell within the range of $80 \%-120 \%$, except those for plasma samples containing hemoglobin, suggesting that the test system is inappropriate to hemolysis-free blood samples (Table V).

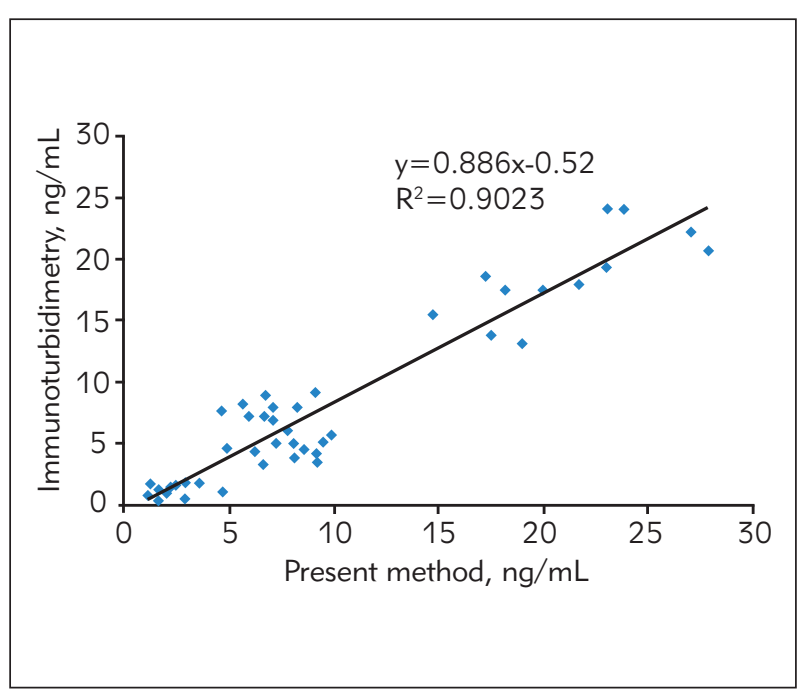

Figure 4 Linear correlation between test system and immunoturbidimetry results.

Fifty clinical plasma samples were tested with the test system and immunoturbidimetry, and the results were comparable $(t=1.985$ and $P>0.05$, paired $t$ test). The linear regression equation was calculated as: $Y=0.886 X-0.52$ (correlation coefficient $r=0.95$, $\mathrm{P}<0.01$ ). 
Comparison of plasma sample test with immunoturbidimetry

To examine the test system with real-world samples, we applied the panel test for 50 clinical serum samples and compared with the results obtained by immunoturbidimetry. The results in Figure 4 indicate that measurements obtained with the two methods were comparable $(t=1.985, P>0.05)$.

\section{Discussion}

A new method for measuring the H-FABP concentration in plasma samples was developed based on the principle of background fluorescence quenching immune chromatography and validated. The developed assay features a wide linear detection range, high repeatability, a low cut-off value, and low inter-batch variation. The whole process is simple and requires less time than conventional methods through the development of a visible T-line on the test pad within $15 \mathrm{~min}$. The appearance of the $\mathrm{C}$-line verifies the validity of test. The degree of background fluorescence quenching is measured by $F_{0} / F_{1}$, which reflects the H-FABP concentration.

The clinical value of $\mathrm{H}$-FABP has been long recognized (15). Its early release following myocardial ischemia and early detection within $30 \mathrm{~min}$ of onset make it a highly effective biomarker for the diagnosis and management of ACS. A gold immunochromatographic assay (GICA) has been developed and applied in diagnostic tests; however, it is a qualitative test in the majority of applications. In the present study, we established a novel, quantitative GICA for $\mathrm{H}-\mathrm{FABP}$ based on fluorescence quenching and nitrocellulose membrane background signal. The test system consisting the test card and test cup was prepared, and the performance of the background fluorescence quenching immunochromatographic assay was assessed. High reproducibility was confirmed using plasma samples, and no interference for the detection of H-FABP was observed in samples containing bilirubin, ascorbic acid, human serum albumin, and human immunoglobulin.

The principle of reaction for the developed assay is quite simple. A plasma sample is first added to the test cup to bind with colloidal gold antibody complex. Then the treated solution is added to the test card. The presence of H-FABP is detected with the appearance of a red T-line on the nitrocellulose membrane. Unlike existing immunochromatographic assays that detect the coating or labeling fluorescence, colloidal gold, or capture antibodies, this background fluores- cence quenching immunochromatographic assay takes advantage of background fluorescein signal on the NC membrane and collects the total fluorescence signal at the C-line, as quality control, and at the Tline. The method is sensitive enough to detect any fluctuation in fluorescence intensity compared with the baseline fluorescence to ensure accurate measurement. Therefore, the assay offers greater tolerance of potential changes in the test system. Moreover, greater sensitivity for the detection of $\mathrm{H}$ FABP has been achieved with extension of the quantitation range to $0-100 \mathrm{ng} / \mathrm{mL}$. In addition, with a minimum detection limit of $1.15 \mathrm{ng} / \mathrm{mL}$. The new method has high sensitivity. Importantly, the new test system does not require the additional purchase of a special device, as existing assays do (15), and the detection period is reduced from $27 \mathrm{~min}$ to $15 \mathrm{~min}$ $(16,17)$. A one-step immunotest for H-FABP has been reported (18), but the effective detection limit was relatively higher $(7 \mathrm{ng} / \mathrm{mL})$ compared with the current system.

Limitations of the present study should be recognized. First, different types of clinical samples, such as whole blood, need to be tested with large sample sizes to further validate the clinical value of the developed assay. Second, we only validated the test system with immunoturbidimetry. However, given that other test measures, such as ELISA, have been widely applied in clinical practice, further comparison may be necessary to distinguish the advantages and disadvantages of the developed assay compared with other measures. Third, the background signal of the plasma sample tested in the study was heterogeneous, which may contribute to individual variation. Moreover, whether the assay can be used to accurately track the dynamic change of H-FABP levels observed in $\mathrm{AMI}$ patients remains to be studied for real-world cases.

In summary, background fluorescence quenching immunochromatography can detect the site of $\mathrm{H}$ FABP fast, and the detection instrument is small and convenient, with low cost. It will be popularized in the community and primary medical institution.

Acknowledgement. The study was approved by the Xinjiang uygur autonomous region science and technology support xinjiang project (2016E02036).

\section{Conflict of interest statement}

The authors stated that they have no conflicts of interest regarding the publication of this article. 


\section{References}

1. Gu M, Ruan XQ, Kang SJ, Liu HF, Yu JN. Preparation of $\mathrm{H}-\mathrm{FABP}$ and cardiac troponin II test strips. Journal of Jiangsu University 2015; 7: 350-2.

2. Huang NS. Fatty acid binding protein in acute myocardial infarction in patients with early diagnosis of the application. Medical Examination 2012; 8: 95-96.

3. Collinson P. Laboratory medicine is faced with the evolution of medical practice. J Med Biochem 2017; 36: 2115.

4. Peng LF, Luo G, Xi ZX. Preparation and preliminary preparation of colloidal gold test strips for myocardial fatty acid - binding. Advances in Microbiology and Immunology 2013; 41: 35-9.

5. Xiong DQ, D.M. Y, Ma T. Colloidal gold immunochromatographic determination of serum myocardial fatty acid binding protein and clinical application. J Lab Med Clin Med; 6: 101-2.

6. Zeng QH, Zhang XW, Xu XL, Jiang MH, Xu KP, Piao JH, et al. Antioxidant and anticomplement functions of flavonoids extracted from Penthorum chinense Pursh. Food Funct 2013; 4: 1811-8.

7. Li MX, Wu XK, Wang XL. Combined detection of $\mathrm{H}-$ FABP, cTNI in the early diagnosis of AMI clinical application. Contemp Med 2012; 3: 47-8.

8. Tarighi $S$, Najafi M, Hossein-Nezhad A, Ghaedi $H_{\text {, }}$ Meshkani R, Moradi N, Fadaei R, Kazerouni F, Shanaki M. Association Between Two Common Polymorphisms of Vitamin D Binding Protein and the Risk of Coronary Artery Disease: a Case-Control Study. J Med Biochem 2017; 36: 349-57.

9. Kang K, Wu P, Li W, Tang S, Wang J, Luo X, et al. Evaluation of a newly developed quantitative heart-type fatty acid binding protein assay based on fluorescence immunochromatography using specific monoclonal antibodies. Scand J Clin Lab Invest 2015; 75: 693-8.
10. Ockner RK, Manning JA. Fatty acid-binging protein in small in-testine. J Clin Invest 1984; 54: 326-38.

11. Wodzig KW, Pelsers MM, van der Vusse GJ, Roos W, Glatz JF. One-step enzyme-linked immunosorbent assay (ELISA) for plasma fatty acid-binding protein. Ann Clin Biochem 1997; 34 (Pt 3): 263-8.

12. Robers M, Van der Hulst FF, Fischer MA, Roos W, Salud $\mathrm{CE}$, Eisenwiener $\mathrm{HG}$, et al. Development of a rapid microparticle-enhanced turbidimetric immunoassay for plasma fatty acid-binding protein, an early marker of acute myocardial infarction. Clin Chem 1998; 44: 1564-7.

13. Watanabe T, Ohkubo Y, Matsuoka H, Kimura H, Sakai $Y$, Ohkaru $Y$, et al. Development of a simple whole blood panel test for detection of human heart-type fatty acidbinding protein. Clin Biochem 2001; 34: 257-63.

14. Chen $X, X u Y, Y u$ J, Li J, Zhou X, Wu C, et al. Antigen detection based on background fluorescence quenching immunochromatographic assay. Anal Chim Acta 2014; 841: 44-50.

15. McCann CJ, Glover BM, Menown IB, Moore MJ, McEneny J, Owens CG, et al. Novel biomarkers in early diagnosis of acute myocardial infarction compared with cardiac troponin T. Eur Heart J 2008; 29: 2843-50.

16. Ishii J, Nagamura Y, Nomura M, Wang JH, Taga S, Kinoshita $M$, et al. Early detection of successful coronary reperfusion based on serum concentration of human heart-type cytoplasmic fatty acid-binding protein. Clin Chim Acta 1997; 262: 13-27.

17. Suzuki K, Sawa Y, Kadoba K, Takahashi T, Ichikawa H, Kagisaki K, et al. Early detection of cardiac damage with heart fatty acid-binding protein after cardiac operations. Ann Thorac Surg 1998; 65: 54-8.

18. Xie PY, Li YP, Chan CP, Cheung KY, Cautherley GW, Renneberg R. A one-step immunotest for rapid detection of heart-type fatty acid-binding protein in patients with acute coronary syndromes. J Immunoassay Immunochem 2010; 31: 24-32. 